\title{
Covid-19 Pandemic and Climate Change: A Review on the Response of Countries to Both Phenomena
}

\author{
Gun Mardiatmoko* \\ Study Program of Forest Management, Postgraduate Program of Pattimura University, Indonesia
}

*Corresponding author: Gun Mardiatmoko, Study Program of Forest Management, Postgraduate Program of Pattimura University, Ambon, Indonesia.

To Cite This Article: Gun Mardiatmoko. Covid-19 Pandemic and Climate Change: A Review on the Response of Countries to Both Phenomena. 2020 - 11(1). AJBSR.MS.ID.001595. DOI: 10.34297/AJBSR.2020.11.001595.

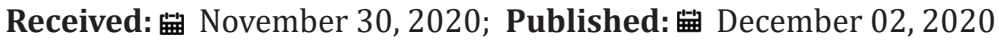

\section{The Beginning of Wuhan, China as the Source of Covid-19}

Since the beginning of the year 2020, the world's population has felt the negative impact of the Covid-19 pandemic. The virus first appeared in Wuhan, China at the end of 2019, and has spread rapidly around the world. It is suspected by many that the virus originated in bats and then infected other animals such as pangolins and dogs before being transmitting to humans at a market in Wuhan, China, through zoonosis. Currently, various countries are competing to immediately create a vaccine against Covid-19. This is because, the lockdown policy implemented by the countries would definitely get a lot of opposition when carried out for a long time. Moreover, a lengthy lockdown can lead to "Cabin Fever Syndrome". Everyone needs to enter the "new normal" period, which means living their lives as usual. However, they need to implement health protocols such as wearing masks, maintaining social distance and washing their hands frequently.

\section{The Appearance of Zoonosis Disease}

Wildlife habitats are natural forests which are located far from human settlements. Therefore, encounters between humans and wild animals are relatively rare. Nonetheless, the anthropogenic activities carried out by humans has led to deforestation and forest degradation, and this has compromised the ability of forests to function properly. Damaged forests therefore only provide little environmental services such as clean water, oxygen, and a comfortable environment where humans can relax. Meanwhile, for wildlife, this damage causes greater problems because the forest habitat is where wild animals reproduce, find food and live. Damage to wildlife habitats cause the animals to become desperate and migrate to human settlements. Consequently, there is an increased chance for their pathogens to infect humans. Due to the local wisdom of indigenous people that also live in forests, there is no course for alarm, regarding them hunting wild animals. This is because they hunt animals for food on a limited basis, using traditional hunting tools. Therefore, problems only arise when there is excessive hunting of illegal wildlife for sale. Cases of rampant selling of wild meat in commercial markets should be limited or even prohibited [1]. Damaged forests somewhat close the distance between human settlements and wildlife habitat. Thus, indirectly, encounters between humans and wildlife are becoming more frequent. This therefore, increases the chances of zoonosis occurring. Most epidemics that develop into pandemics occur due to zoonosis. This means that the diseases made a jump from their habitat or animal shelter to humans. Therefore, it is not surprising that due to the dangers of the Covid-19 virus, the Danish Minister of Health destroyed 15 million mink (Mustelidae) in Denmark for transmitting the corona virus to humans [2]. Along with the emergence of the pandemic there have been strange events of large numbers of animals dying suddenly, such as, (1) the birds that fell from the sky at night in the city of Philadelphia, USA, estimated to be around 1,500 [3], (2) the thousands of dead fishes that washed up on the shores of South Florida's Biscayne Bay [4], and (3) the hundreds of elephants that dead mysteriously in Botswana [5].

Differences in Actions to Deal with the Covid-19 Pandemic and Climate Change

The emergence of the Covid-19 pandemic is inseparable from the impact of climate change. In addition, the governments of both developed and developing countries have almost the same attitude in dealing with pandemics, but very different in dealing with climate change. Meanwhile, when considering at the impacts of climate change, they are worse than that of pandemics. Covid-19 does not consider a person's status. The virus does not care whether a person 
is a State official, artist, civil servant, private entrepreneur or just an ordinary person. At least, that is what makes the governments of both developed and developing countries unite in dealing with the virus, especially by competing to produce a vaccine.

When it comes to dealing with climate change, countries put on different attitudes. So far, the handling of the problem has been carried out by implementing the REDD + program, namely by implementing climate change mitigation and adaptation activities. Developing countries demand that the developed counterparts provide more funding because they contribute a large amount of GHG to the atmosphere which causes global warming. In addition, countries like the United States, which is the second highest producer of GHG no longer want to be bound by the Paris Agreement for handling climate change. Therefore, on the 4th of November, in the midst of their 2020 presidential election, the country officially opted out of the agreement [6]. This increased the possibility that the decisions which will be made in 26th meeting of the Conference of the parties (COP), will not be accepted by each participating country. The British Prime Minister has been trying to encourage countries that are members of the world's major economies (G20) to play a more active role in dealing with climate change. This is because, it will allow citizens round the world to more quickly anticipate and adapt to the impacts of the change, such as weather anomalies, melting polar ice caps, rising sea levels and various other natural disasters. The future of the world depends on these countries taking ambitious steps in dealing with the problem [7].

\section{Conclusion}

The impact of climate change is actually much worse than the Covid-19 pandemic. Therefore, the same perception and level of action carried out by both developing and developed countries in dealing with the virus should be given to the problem of climate change, in order to create a better world for the future generation.

\section{References}

1. Higonnet E (2020) Pandemi corona, waktunya aksi nyata setop deforestasi dan perdagangan satwa.

2. CNN Indonesia (2020) Tulari Covid ke Manusia, 15 Juta Cerpelai di Denmark Dibunuh.

3. CNBC Indonesia (2020) Pertanda Apakah Ini? Ribuan Burung Mati Jatuh dari Langit.

4. Childs JW (2020) Thousands of Dead Fish Wash Up on Shores of South Florida's Biscayne Bay.

5. The Guardian (2020) Hundreds of elephants dead in mysterious mass die-off.

6. Channel New Asia (2020) US withdraw Paris Agreement climate change.

7. Aini N (2020) Perdana Menteri Inggris dorong G20 lebih aktif hadapi perubahan iklim. 